\title{
8. PALEOCENE THROUGH MIDDLE EOCENE PLANKTONIC FORAMINIFERS FROM HOLE 807C, ONTONG JAVA PLATEAU ${ }^{1}$
}

\author{
Isabella Premoli Silva ${ }^{2}$
}

\begin{abstract}
Paleocene through middle Eocene sediments from Hole 807C (Ontong Java Plateau), Ocean Drilling Program Leg 130, consist of limestones studied in thin section. Sedimentary features include common strong sorting and grading accompanied with laminations, and discrete turbiditic layers. These features strongly affected the distribution and preservation of planktonic foraminifers, which accordingly were generally heavily reworked and sorted. Biostratigraphic assignments were based on rare to few specimens of younger ages largely overwhelmed by much older faunas. The planktonic foraminifer record, however, is not continuous and elements of some biozones were not detected, including those from Subzones Plc through P3a of the Paleocene and Subzone P6a through Zone P10 of the early to middle Eocene. The top of the section studied possibly belongs to late Eocene Zone P15.
\end{abstract}

\section{INTRODUCTION}

This paper deals with the study of Paleocene to Eocene planktonic foraminifers of Hole $807 \mathrm{C}$, drilled on the northern rim of the Ontong Java Plateau $\left(3^{\circ} 36.39^{\prime} \mathrm{N}, 156^{\circ} 37.48^{\prime} \mathrm{E}\right)$ at a water depth of $2805.7 \mathrm{~m}$. The site was positioned in a shallow basement graben to retain a thick sedimentary section, including a complete section of the Paleogene and Cretaceous, and yet avoid the problems of current winnowing and bottom transport encountered at other drilling sites on the plateau. Hole $807 \mathrm{C}$ was washed to $780.0 \mathrm{mbsf}$ and then rotary drilled to 1528.4 mbsf; more than $100 \mathrm{~m}$ of basement was penetrated. The Paleogene section investigated here is $>100 \mathrm{~m}$ thick from 1092.0 to $1197 \mathrm{mbsf}$, at which point the Cretaceous/Paleocene boundary was encountered based on planktonic foraminifers (see Corfield et al., this volume). Recovery was poor to medium in the interval studied.

According to the shipboard description (Kroenke, Berger, Janecek, et al., 1991), Paleogene sediments recovered from Cores 130807C-40R to $-55 \mathrm{R}-1$ (1092.0-1197 mbsf) belong to Subunit IIB, except for the topmost core (130-807C-40R), which represents the base of Subunit IIA. Subunit IIB is composed primarily of white limestone with a subordinate grey color and silicified limestone to a depth of $1140 \mathrm{mbsf}$ (Core 130-807C-46R included). Chert is present throughout, but its abundance rarely exceeds $10 \%$ of the recovered material. Microscopically, Subunit IIB is characterized by a transition from material dominated by nannofossils to material dominated by carbonate particles, especially up to $1140 \mathrm{mbsf}$. In the interval between 1116 and 1135 mbsf (Cores 130-807C-44R and -45R), white limestone clasts up to $5 \mathrm{~mm}$ in diameter of Late Cretaceous age were found as well as a 5-cm-thick, finely laminated bed containing only lower Eocene nannofossils.

\section{METHODS}

The present study is based on 66 samples generally collected every meter, except in Cores 130-807C-54R-4 and -55R-1 where samples are spaced from 1 to $20 \mathrm{~cm}$ (Table 1). The study used thin sections oriented across the bedding plane when possible. No isolated foraminifers were obtained as the sediments were too lithified.

\footnotetext{
'Berger, W.H., Kroenke, L.W., Mayer, L.A., et al., 1993. Proc. ODP, Sci. Results, 130: College Station, TX (Ocean Drilling Program).

${ }^{2}$ Dipartimento di Scienze della Terra, Università degli Studi di Milano, via Mangiagalli 34, I-20129 Milano, Italy.
}

The identification of planktonic foraminifers in thin section was based on the internal and external shapes of individual foraminifers examined in axial and transverse sections. Most of the diagnostic criteria were recognized in the axial section and include the size and shape of the text; the thickness and texture of the wall; the size, shape, number, and arrangement of chambers; and the type of ornamentation such as ridges, spines, muricae, and peripheral thickening. Occasionally, the position and shape of the aperture were visible. Also important among the Paleogene planktonic foraminifers is the type of wall, which is very diagnostic at the generic level (Hemleben et al., 1991).

\section{PLANKTONIC FORAMINIFER BIOSTRATIGRAPHY}

A detailed study of planktonic foraminifer faunas revealed that all Paleogene sediments are resedimented and that planktonic faunas are largely affected by reworking, although the location of Site 807 was chosen to avoid winnowing and bottom transport. The preservation of planktonic foraminifers is very uneven from layer to layer but generally is poor, frequently with forms heavily recrystallized and less frequently dissolved and deformed. Size sorting is very important throughout and was detected either in a single thin section or by comparing different closely spaced samples. Moreover, the various size fractions from silt to sand are composed of planktonic foraminifers of different genera and ages that change upsection. The trend is toward a progressively younger age of reworked forms, but Late Cretaceous foraminifers are still present and mixed with much younger Eocene faunas. As described in a previous study from the Nauru Basin (Premoli Silva and Violanti, 1981), reworked forms almost constantly overwhelm the youngest ones, which apparently never exceed $5 \%$ of the total assemblage. According to the resedimented character of the sediments, the abundance of planktonic foraminifers varies from an almost complete absence and very small sizes $(<40$ $\mu \mathrm{m})$ to packed but still of small sizes $(<150 \mu \mathrm{m})$, to packed but of larger sizes (about $250 \mu \mathrm{m}$ ). Rarely are the assemblages composed of normal-sized forms; in these cases, however, the fine fraction is scarce. When planktonic foraminifers of whatever size are very abundant, micrite is almost completely missing. On the contrary, when micrite makes up almost $100 \%$ of the rock, foraminifers are very rare. Occasionally, the micrite-rich samples yield partially dissolved, deformed planktonic forms especially of larger size, suggesting that carbonates underwent dissolution during deposition and/or diagenesis. The peculiarity of the sedimentation in the cores studied is clearly registered in the logs, especially in the sonic log (Kroenke, Berger, Janecek, et al., 1991, pp. 482-483). 
Table 1. List of samples investigated.

130-807C-40R-1, $51-52 \mathrm{~cm}$ 130-807C-40R-2, $4-6 \mathrm{~cm}$

130-807C-41R-1, $53-55 \mathrm{~cm}$

130-807C-42R-1, 71-73 cm

130-807C-43R-1, $1-3 \mathrm{~cm}$

130-807C-43R-1, 115-117 cm

130-807C-44R-1, 6-7 cm

130-807C-44R-1, 91-93 cm

130-807C-45R-2, 5-7 cm

130-807C-46R-1, 30-32 cm

130-807C-46R-1, 130-132 cm

130-807C-46R-2, $75-77 \mathrm{~cm}$

130-807C-46R-3, 45-46 cm

130-807C-47R-1, $4-6 \mathrm{~cm}$

130-807C-47R-1, $102-106 \mathrm{~cm}$

130-807C-47R-2, 46-48 cm

130-807C-48R-1, 37-39 cm

$130-807 \mathrm{C}-48 \mathrm{R}-1,140-142 \mathrm{~cm}$

130-807C-48R-2, 88-90 cm

130-807C-49R-1, $13-15 \mathrm{~cm}$

130-807C-49R-1, 103-105 cm

130-807C-50R-1, 4-6 cm

130-807C-50R-1, $107-109 \mathrm{~cm}$

130-807C-50R-2, $42-43 \mathrm{~cm}$

130-807C-51R-1, $3-5 \mathrm{~cm}$

130-807C-51R-1, 105-107 cm

130-807C-51R-2, $47-48 \mathrm{~cm}$

130-807C-51R-2, $148-150 \mathrm{~cm}$

130-807C-51R-3, $94-96 \mathrm{~cm}$

130-807C-52R-1, $19-21 \mathrm{~cm}$
130-807C-42R-2, $11-13 \mathrm{~cm}$

130-807C-45R-1, $56-58 \mathrm{~cm}$

$130-807 \mathrm{C}-51 \mathrm{R}-4,4-5 \mathrm{~cm}$

130-807C-52R-1, $114-116 \mathrm{~cm}$ 130-807C-52R-2, $81-83 \mathrm{~cm}$ 130-807C-52R-3, $19-21 \mathrm{~cm}$ 130-807C-52R-3, $115-117 \mathrm{~cm}$ 130-807C-52R-4, 31-33 cm 130-807C-53R-1, $28-30 \mathrm{~cm}$ 130-807C-53R-1, $121-123 \mathrm{~cm}$ 130-807C-53R-2, 65-67 cm 130-807C-53R-3, 22-24 cm 130-807C-53R-3, 120-122 cm 130-807C-53R-4, $58-60 \mathrm{~cm}$ 130-807C-53R-5, 10-12 cm 130-807C-54R-1, 8-10 cm 130-807C-54R-1, $119-121 \mathrm{~cm}$ 130-807C-54R-2, 83-85 cm 130-807C-54R-3, 35-37 cm 130-807C-54R-3, $137-139 \mathrm{~cm}$ 130-807C-54R-4, 20-22 cm 130-807C-54R-4, 31-32 cm 130-807C-54R-4, 62-64 cm 130-807C-54R-4, 89-90 cm 130-807C-54R-4, 113-114 cm 130-807C-54R-4, 125-126 cm 130-807C-54R-4, 135-136 cm 130-807C-54R-4, 148-149 cm 130-807C-54R-4, 149-150 cm 130-807C-55R-1, $9-11 \mathrm{~cm}$ 130-807C-55R-1, $14-16 \mathrm{~cm}$ $130-807 \mathrm{C}-55 \mathrm{R}-1,22-24 \mathrm{~cm}$ 130-807C-55R-1, $25-26 \mathrm{~cm}$ $130-807 \mathrm{C}-55 \mathrm{R}-1,31-33 \mathrm{~cm}$ $130-807 \mathrm{C}-55 \mathrm{R}-1,35-36 \mathrm{~cm}$ 130-807C-55R-1, $49-50 \mathrm{~cm}$

In such conditions, biostratigraphic assignments are difficult, and we have to rely on the occurrence of the scarce youngest taxa recorded in a sample without a continuity of the record itself. That prevents a reliable construction of the distribution chart, which is replaced by a synthetic $\log$ in which the most reliable biostratigraphic events, plotted against sub-bottom depths and recovery, are used for zonal assignment and, consequently, age.

\section{Microfacies}

On the basis of the type of planktonic foraminifers making up the bulk of the assemblages and the sedimentary features detected in the microfacies, a few discrete intervals can be recognized in the sequence recovered from Hole 807C, Cores 130-807C-55R-1 to -40R included. They are as follows from bottom to top (see Figs. 1 and 2):

1. The oldest samples (4) analyzed (Sample 130-807C-55-1, from $35-36$ to $22-24 \mathrm{~cm}$ ) are almost totally micritic and yield only rare to few, poorly preserved specimens attributable to small Paleogene eoglobigerinids (Plate 1, Fig. 1) and possibly chiloguembelinids (Fig. 2). Late Cretaceous forms are also scarce and poorly preserved with a large number of them dissolved, deformed, and broken. They are also size sorted, and small- to medium-sized specimens dominate the faunas that include rare keeled forms.

2 . The 13 samples from the second interval (Samples 130-807C$55 \mathrm{R}-1,14-16 \mathrm{~cm}$, to $-54 \mathrm{R}-2,83-85 \mathrm{~cm})$ are characterized by extremely abundant, small-sized $(<150 \mu \mathrm{m})$, Cretaceous planktonic foraminifers, literally packed without micrite, alternatively associated with rare to abundant Guembelitria and rare Woodringina in the lower part (Plate 1, Figs. 2 and 3) and by more common woodringinids and rare to few Guembelitria toward the top of the interval. Late Cretaceous planktonic foraminifers predominantly belong to Globigerinelloides and to a minor extent to Heterohelix, rare Pseudotextularia, and very rare Hedbergella. Occasionally rare, mainly juvenile, speci- mens of globotruncanids and planoglobulinids are also recorded. Few samples display evidence of grading, sorting, and lamination (Plate 1, Fig. 4). These are richer in micrite, which contains very minute calcitic fragments, probably from destroyed larger planktonic foraminifers; the micrite occasionally is recrystallized in microsparite. Burrows are distinctly visible in a few thin sections and may be more recrystallized than the matrix or infilled by larger, more normal-sized planktonic foraminifers.

3 . The 6 samples from the third interval (Samples 130-807C-54R$1,119-121 \mathrm{~cm}$, to $-53 \mathrm{R}-3,22-24 \mathrm{~cm}$ ) are more laminated and bioturbated than previously observed, but they are substantially similar to those from the underlying interval with regard to such sedimentary characters as micritic vs. packed layers, and so on. The turbiditic character of the sequence is well represented by Sample 130-807C53R-5, 10-12 cm (Plate 2, Fig. 3); the oriented thin section cuts the base of a turbidite that is marked by an accumulation of planktonic foraminifers, including larger globotruncanids lying on a micritic layer almost devoid of planktonic faunas. What differentiates this interval from the underlying one is the foraminiferal content, which is dominated by early to middle Paleocene planktonic foraminifers, whereas Late Cretaceous forms, although present, are generally rare (Plate 2, Fig. 1) and/or confined to the base of the turbidites. Sample 130-807C-53R-3, 120-122 cm, contains common to abundant radiolarians and few planktonic foraminifers and is partially silicified (Plate 2, Fig. 4).

4. Fourteen samples belong to the fourth interval (Samples 130-807C$53 \mathrm{R}-2,65-67 \mathrm{~cm}$, to $-51 \mathrm{R}-1,105-107 \mathrm{~cm}$ ), and they are constantly laminated and display fluidal structures and common burrows. The main feature, however, of this interval is related to the planktonic faunas, which contain strongly dissolved specimens throughout, especially in the micrite-rich samples (Plate 2, Fig. 5). Grading was observed in some samples. The faunal composition is markedly changed with respect to the underlying intervals. Late Paleocene species dominate and morozovellids are abundant in some samples, whereas moderately abundant Late Cretaceous globotruncanids are confined to a few layers.

5. Thirteen samples belong to the fifth interval (Samples 130-807C$51 \mathrm{R}-1,3-5 \mathrm{~cm}$, to $-46 \mathrm{R}-3,45-47 \mathrm{~cm})$. As in the interval below, they are constantly laminated with common fluidal structures and discrete grading. The main feature concerns planktonic foraminifer preservation, which fades from very poor to moderate (Plate 3, Figs. 1-4); but commonly planktonic foraminifers are dissolved and/or reduced to minute fragments. Micrite-bearing samples become more common, but the micrite frequently is strongly recrystallized. Planktonic assemblages range from dominated to overwhelmed by late Paleocene forms. A few layers contain some amount of Late Cretaceous and earliest Eocene forms. The youngest middle Eocene specimens never exceed the $5 \%$ of the total fauna. Radiolarians are rarely recorded.

6. Twelve samples belong to the sixth interval (Samples 130$807 \mathrm{C}-46 \mathrm{R}-2,75-77 \mathrm{~cm}$, to $-41 \mathrm{R}-1,53-55 \mathrm{~cm}$ ), a very thick interval with poor recovery. The samples investigated probably represent only the most lithified portions of the sedimentary succession. The sedimentary features in this interval are similar to the underlying ones and include laminations, fluidal structures, and bioturbation (Plate 4, Fig. 3). The more common micrite-bearing samples are strongly silicified. Silicification also affected the planktonic foraminifers, which are not only silicified but frequently dissolved. Better preservation is shown by the reworked forms. Planktonic foraminifers vary in abundance from almost absent to extremely abundant. In the latter case, planktonic faunas are predominantly of early to early middle Eocene age with some Late Cretaceous forms. Radiolarians may be common in some samples but their preservation is poor.

7. The topmost two samples are Samples 130-807C-40R-2, 4-6 $\mathrm{cm}$, and $-40 \mathrm{R}-1,51-52 \mathrm{~cm}$. In thin section the sediments appear to be undisturbed and the matrix is micritic. Planktonic foraminifers, although common, are still partially dissolved. Reworking may be present if the zonal assignment of the late Eocene Zone P15 is confirmed (see below). 


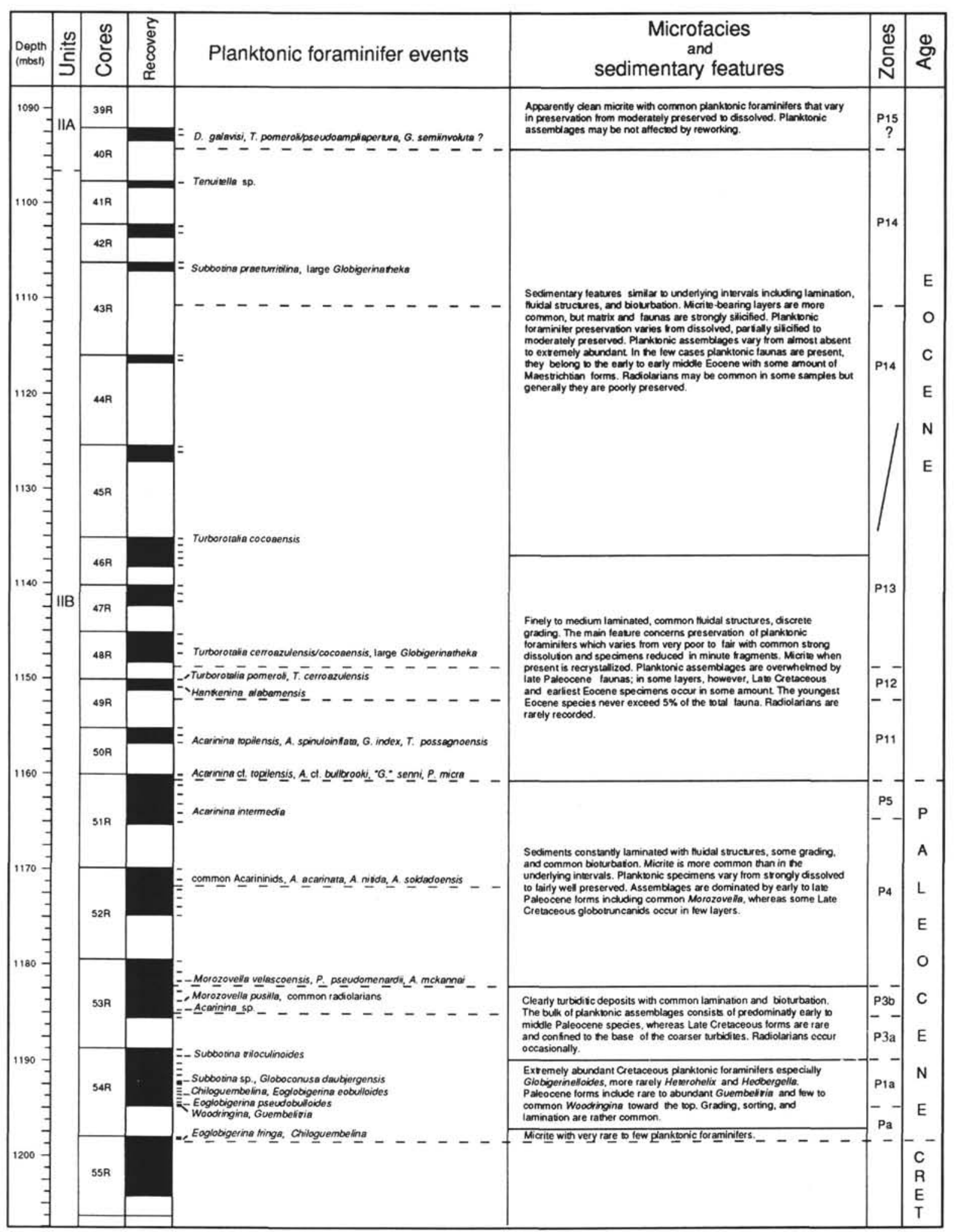

Figure 1. Synthetic log from Core 130-807C-40R to Sample 130-807C-55R-1, $50 \mathrm{~cm}$, spanning the interval from the top of the Cretaceous through possibly the base of the upper Eocene. Included are depths in meters, core numbers, recovery, sample position, planktonic foraminifer events, and microfacies and sedimentary features plotted vs. planktonic foraminifer biozones and age. Zonal scheme after Berggren et al. (1985) and Berggren and Miller (1988). 


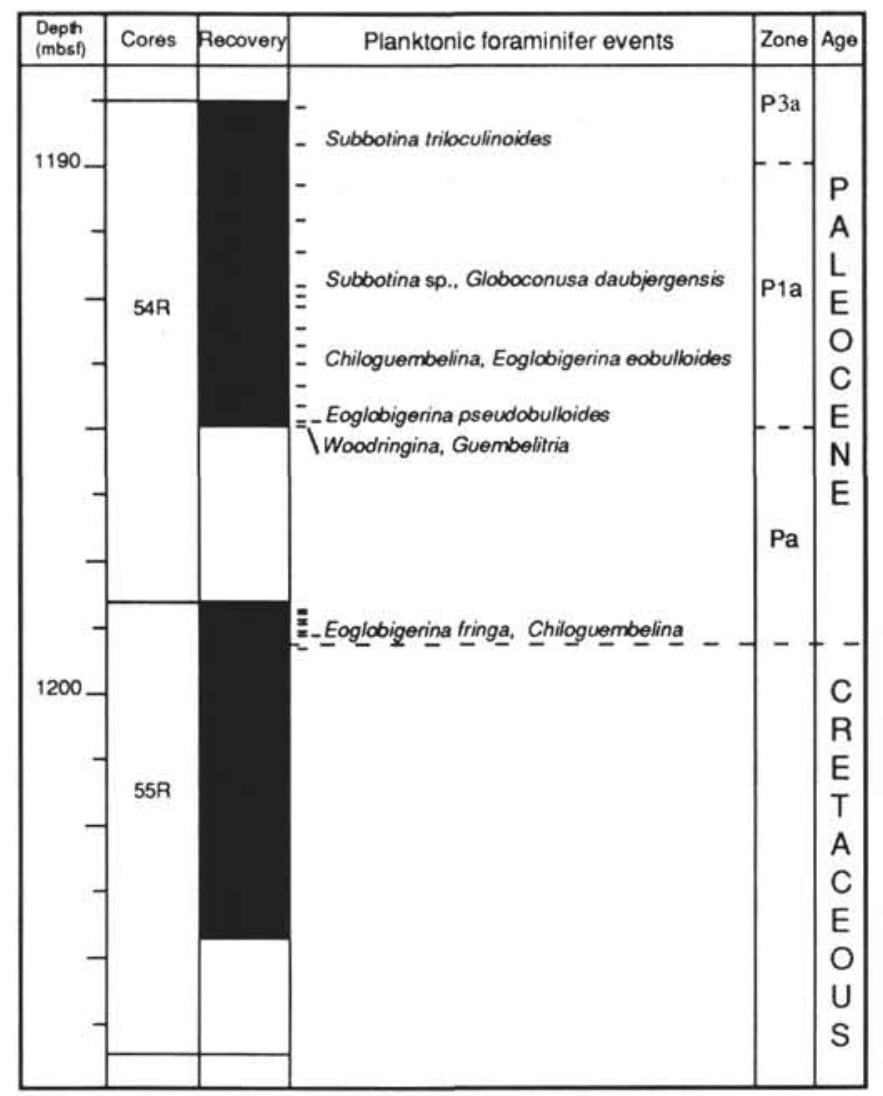

Figure 2. Closeup of the log in Figure 1 for Cores 130-807C-54R and -55R with sample position and planktonic foraminifer events plotted vs. planktonic foraminifer biozones and age. Zonal scheme as in Figure 1.

\section{Planktonic Foraminifer Events}

Biostratigraphy of these reworked sediments relies on the youngest species, but the age must be considered as a minimum age. The zonal scheme by Berggren et al. (1985) and Berggren and Miller (1988), and the planktonic foraminifer ranges of Boersma and Premoli Silva (1983) and Premoli Silva and Boersma (1988) are applied here. The most important events detected in the studied sequence are as follows (from oldest to youngest) (Figs. 1 and 2):

1. Sample 130-807C-55R-1,35-36 cm, the lowest sample studied, yielded rare to few, small globigerinids with four chambers, which may be attributable to Eoglobigerina fringa, and rare thin biserial heterohelicids close to Chiloguembelina (Fig. 3). The occurrence of these taxa indicates the base of the Paleocene and specifically Zone $\mathrm{P} \alpha$ (= P. eugubina Zone). Also occurring in these sample are few, poorly preserved and/or dissolved, late Maastrichtian specimens including planoglobulinids, Pseudotextularia elegans, few Globigerinelloides, rugoglobigerinids, pseudoguembelinids, and a single specimen of a possible Abathomphalus.

2 . Very rare specimens of small rotaliforms, mainly not identified at species level with one possibly belonging to Eoglobigerina fringa of early Paleocene age, occur in Sample 130-807C-55R-1, 26-27 cm (Plate 1, Fig. 1). This finding is consistent with the occurrence of $E$. fringa and possible Chiloguembelina in Sample 130-807C-55R-1, $35-36 \mathrm{~cm}$.

3. In Sample 130-807C-54R-4, 149-150 cm, the planktonic foraminifer assemblages are dominated by Late Cretaceous faunas, but they also contain abundant Guembelitria and some Woodringina (Plate 1, Fig. 2). According to several authors (e.g., Smit, 1982; Keller,
1988 , 1989), the latter genus is known to appear in Zone $\mathrm{P} \alpha$, whereas the guembelitrids, which occur in abundance at the Cretaceous/Paleocene boundary, could be partially reworked.

4. In Sample 130-807C-54R-4, 148-149 cm, some honeycomb wall fragments may belong to the genus Eoglobigerina and rare forms seem attributable to Eoglobigerina pseudobulloides. This assignment, if correct, identifies Subzone P1a. More common specimens of E. pseudobulloides occur in Sample 130-807C-54R4, 113-114 cm, associated with Eoglobigerina eobulloides (Plate 1, Fig. 3), rare to few Chiloguembelina spp., and common, possibly reworked woodringinids.

5. Globoconusa daubjergensis and Subbotina sp. occur in Samples 130-807C-54R-4, 89-90 cm, and -54R-4, 20-22 cm, respectively.

6. The first subacute rotaliform occurs in Sample 130-807C-54R-1, 119-122 cm, associated with Subbotina triloculinoides and E. pseudobulloides among other Paleocene forms, whereas the reworked Cretaceous specimens are rare.

7. The first Acarinina is recorded in Sample 130-807C-53R-4, $58-60 \mathrm{~cm}$, followed by a rich morozovellid assemblage in Sample 130-807C-53R-3, 120-122 cm, where Morozovella angulata (Plate 2, Fig. 4), M. abundocamerata, $M$. aequa, and $M$. pusilla were identified. The morozovellids are abundant in Sample 130-807C53R-3, 20-24 cm.

8. Sample 130-807C-53R-2, 65-67 cm, yields Morozovella velascoensis and Planorotalites cf. pseudomenardii (see also Plate 2, Fig. 5).

9. Sample 130-807C-51R-3, 94-96 cm, yields common acarininids such as $A$. intermedia, A. nitida, and $A$. soldadoensis along with Morozovella velascoensis in the absence of $P$. pseudomenardii and M. pusilla. This assemblage suggests that Zone P5 may be present.

10. Sample 130-807C-51R-1, 3-5 cm, yields a much younger species such as Acarinina pseudotopilensis and transitional forms to A. topilensis, A. bullbrooki, A. spinuloinflata, A. rohrillibyaensis, Turborotalia frontosa, Pseudohastigerina micra, and "Globigerinatheka" senni (Plate 3, Figs. 1-4) within a fauna dominated by late Paleocene morozovellids. Acarinina topilensis, A. spinuloinflata, Turborotalia possagnoensis, and possibly Globigerinatheka index are recorded from Sample 130-807C-50R-2, 42-43 cm. This finding is consistent with the species mentioned from the previous sample and suggests that sediments from the top of Core 130-807C-51R are middle Eocene in age and may be attributable to Zone P11.

11. In Sample 130-807C-49R-1, 103-105 cm, Hantkenina alabamensis, "Globorotalia" bolivariana, Morozovella lehneri, Turborotalia cerroazulensis $\mathrm{gr}$., and rare globigerinathekids were identified among the overwhelming late Paleocene forms. The fact that sediments of this core can be dated as middle Eocene Zone P12 is confirmed by the occurrence of Turborotalia pomeroli and $T$. cerroazulensis s. str. in Sample 130-807C-49R-1, 13-15 cm.

12. Forms transitional between Turborotalia cerroazulensis and $T$. cocoaensis occur associated with large globigerinathekids and $T$. pomeroli in Sample 130-807C-48R-2, 88-89 cm (Plate 4, Fig. 1). They indicate Zones P13 or P14. This attribution is corroborated by the presence of rare specimens of $T$. cocoaensis in Sample 130-807C46R-1, 30-32 cm (Plate 4, Fig. 5).

13. The occurrence of Subbotina praeturritilina and numerous large globigerinathekids in Sample 130-807C-43R-1, 115-117 cm, seems to indicate that we are still dealing with sediments attributable to Zone P14, but higher in the zone. This attribution is confirmed by the presence of tenuitellids in Sample 130-807C-41R-1, 53-55 cm, along with Globigerinatheka index and Acarinina rohri.

14. The penultimate sample studied (Sample 130-807C-40R-2,4-6 $\mathrm{cm}$ ) yields Dentoglobigerina galavisi and transitional forms between Turborotalia pomeroli and T. pseudoampliapertura along with a doubtful specimen of Globigerinatheka semiinvoluta. The occurrence of these taxa suggests that the sediments were deposited during late Eocene Zone P15. Based on this interpretation, the muricate forms, still present in Core 130-807C-40R, might be considered reworked. 


\section{CONCLUSIONS}

In summary, the sedimentary succession studied here (from Samples $130-807 \mathrm{C}-55 \mathrm{R}-1,35-36 \mathrm{~cm}$, to $-40 \mathrm{R}-1,51-52 \mathrm{~cm}$ ) can be attributed to the following planktonic foraminifer zones (from oldest to youngest) (see Fig. 1):

Zone $\mathrm{P} \alpha$ (possibly): Samples $130-807 \mathrm{C}-55 \mathrm{R}-1,35-36 \mathrm{~cm}$, to $-54 \mathrm{R}-4,149-150 \mathrm{~cm}$;

Subzone P1a: Samples 130-807C-54R-4, 148-149 cm, to -54R-2, $83-85 \mathrm{~cm}$;

Subzone P3a?: possibly in Sample 130-807C-54R-1, 119-122 cm; Subzone P3b: Samples 130-807C-53R-4, 58-60 cm, to -53R-3, 20-24 cm;

Zone P4: Samples 130-807C-53R-2, 65-67 cm, to -51R-4, 4-5 cm; Zone P5: Samples 130-807C-51R-3, 94-96 cm, to -51R-1, 105$107 \mathrm{~cm}$;

Zone P11: Samples 130-807C-51R-1, 3-5 cm, to -50R-1, 4-6 cm;

Zone P12 to P13?: Samples 130-807C-49R-1, 103-105 to 13-15 cm;

Zones P13 to P14: Samples 130-807C-48R-2, 88-89 cm, to -44R-

$1,6-7 \mathrm{~cm}$

late Zone P14: Samples 130-807C-43R-1, 115-117 cm, to-41R-1, $53-55 \mathrm{~cm}$;

Zone P15?: Samples 130-807C-40R-1, 51-52 and 4-6 cm.

Faunal elements of some zones could not be identified as either they are masked by the heavy reworking or they were not redeposited at the drill site. No record of Subzone P1b through most of Subzone P3a, late Zone P5 through Zone P10, and possibly part of Zones P12 and $\mathrm{P} 13$ was found. Moreover; Zone $\mathrm{P} \alpha$ is tentatively identified at the top of Core 130-807C-55R, although several important species, including Parvorugoglobigerina eugubina, were not observed.

The ages based on planktonic foraminifers strongly disagree with those derived from calcareous nannofossils and radiolarians (Kroenke, Berger, Janecek, et al., 1991). These discrepancies are related to the resedimented character of the studied sequence associated with the poor preservation of both fossil groups. The fact that the youngest planktonic foraminifers are only occasionally present without regard to any patterns, except for a generalized rejuvenation throughout, and are generally overwhelmed by the older reworked forms suggests that the other fossil groups might also be affected by the same phenomena. The advantage of planktonic foraminifers in this case resides in the fact that the study was conducted in thin section. This technique preserves the original relationship between fine (micritic) and larger fractions, and the overall shape of the specimens, even when poorly preserved, can ultimately be identified.

\section{ACKNOWLEDGMENTS}

The author is indebted to ODP for providing the samples for this study. The author would like to thank R. Corfield, W.V. Sliter, and J. Beckman for fruitful discussions about the biostratigraphic problems and isotope curve. Thanks go also to $\mathrm{C}$. Malinverno for thin section preparation, and especially to W.V. Sliter who kindly helped in taking the photomicrographs. This work was supported by the Italian Ministry of University and Technology (MURST), Grant 40\%-1990.

\section{REFERENCES}

Berggren, W.A., Kent, D.V., and Flynn, J.J., 1985. Jurassic to Paleogene: Part 2. Paleogene geochronology and chronostratigraphy. In Snelling, N.J. (Ed.), The Chronology of the Geological Record. Mem. Geol. Soc. (London), 10:141-195.

Berggren, W.A., and Miller, K.G., 1988. Paleogene tropical planktonic foraminiferal biostratigraphy and magnetobiochronology. Micropaleontology, 34(4):362-380.

Boersma, A., and Premoli Silva, I., 1983. Paleocene planktonic foraminiferal biogeography and the paleoceanography of the Atlantic Ocean. Micropaleontology, 29(4):355-381.

Hemleben, C., Mohlen, D., Olsson, R.K., and Berggren, W.A., 1991. Surface texture and the first occurrence of spines in planktonic foraminifera from the early Tertiary. Geol. Jahrb., A128:117-146.

Keller, G., 1988. Extinction, survivorship and evolution of planktonic foraminifers across the Cretaceous/Tertiary boundary at El Kef, Tunisia. Mar. Micropaleontol., 13:239-263.

, 1989. Extended Cretaceous/Tertiary boundary extinctions and delayed population change in planktonic foraminifera from Brazos River, Texas. Paleoceanography, 4(3):287-332.

Kroenke, L.W., Berger, W.H., Janecek, T.R., et al. 1991. Proc. ODP, Init. Repts., 130: College Station, TX (Ocean Drilling Program).

Premoli Silva, I., and Boersma, A., 1988. Atlantic Eocene planktonic foraminiferal historical biogeography and paleohydrographic indices. Palaeogeogr., Palaeoclimatol., Palaeoecol., 67(3/4):315-356.

Premoli Silva, I., and Violanti, D., 1981. Cenozoic planktonic foraminifer biostratigraphy of Deep Sea Drilling Project Hole 462, Nauru Basin (western equatorial Pacific), and distribution of pelagic components. Init. Repts. DSDP, 61: Washington (U.S. Govt. Printing Office), 397-422.

Smit, J., 1982. Extinction and evolution of planktonic foraminifera after major impact at the Cretaceous/Tertiary boundary. Spec. Paper, Geol. Soc. Am., 190:329-352.

Date of initial receipt: 10 December 1991

Date of acceptance: 22 April 1992

Ms 130B-013 

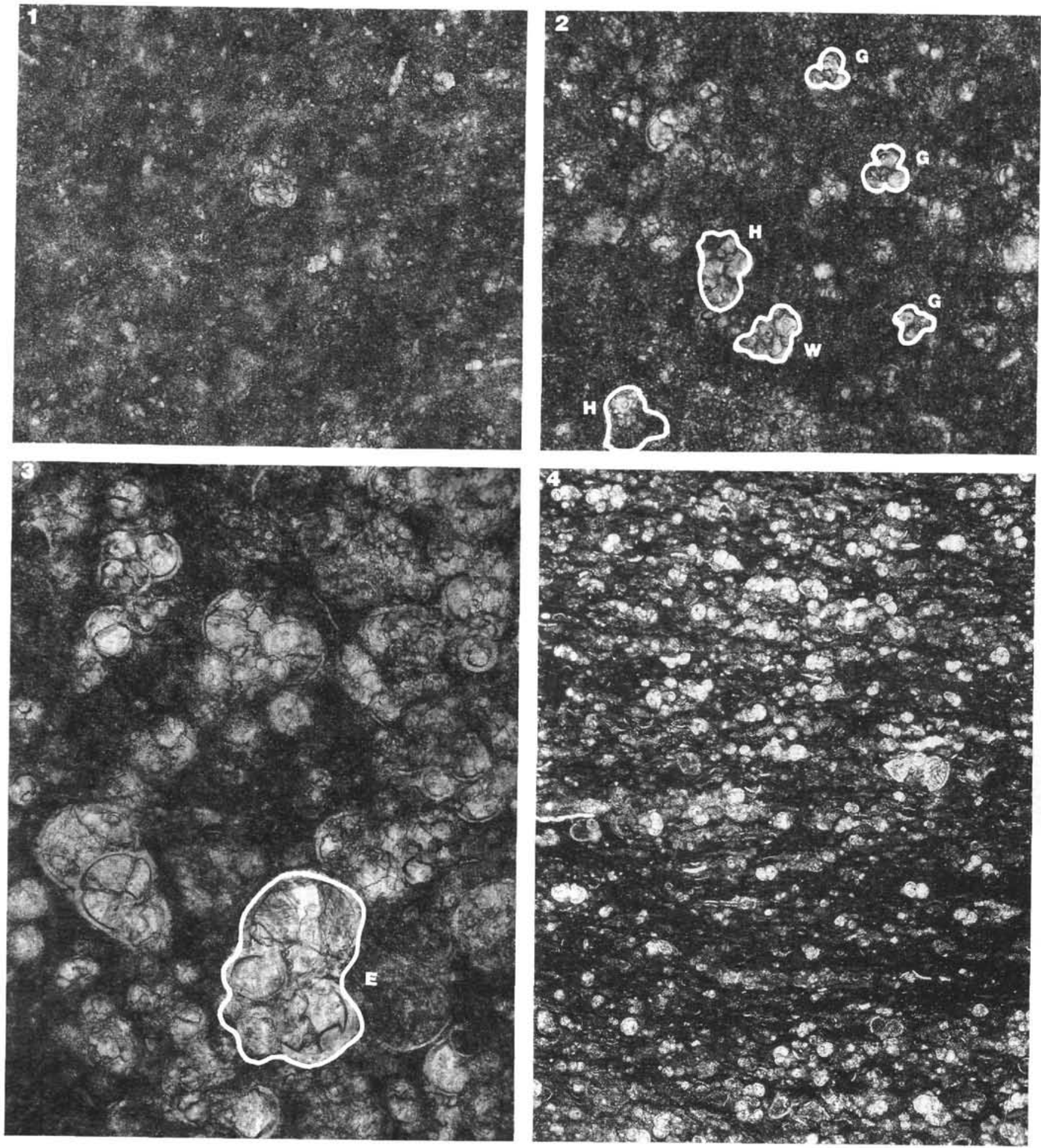

Plate 1. 1. Photomicrograph of Sample $130-807 \mathrm{C}-55 \mathrm{R}-1,25-26 \mathrm{~cm}$, showing very rare and sparse, very small planktonic foraminifers with minute calcitic grains In the center a possible Eoglobigerina fringa. Zone P $\alpha$, early Paleocene; $\times 150$ magnification. 2. Photomicrograph of Sample $130-807 \mathrm{C}-54 \mathrm{R}-4,148-149 \mathrm{~cm}$, containing common planktonic foraminifers, including Guembelitria $(\mathrm{G})$, Woodringina $(\mathrm{W})$, and several Cretaceous biserial heterohelicids $(\mathrm{H})$. Eoglobigerine pseudobulloides is not visible. Subzone Pla, early Paleocene; $\times 150$ magnification. 3. Photomicrograph of Sample $130-807 \mathrm{C}-54 \mathrm{R}-4,113-114 \mathrm{~cm}$, containing very abundant planktonic foraminifers almost without micrite. Note Eoglobigerina eobulloides (E) associated with mainly heterohelicids. Subzone P1a, early Paleocene; $\times 150$ magnification. 4. Photomicrograph of Sample 130-807C-54R-2, 83-85 cm, cut through a turbidite some millimeters thick; $\times 30$ magnification. Note the concentration and subsequent grading of size-sorted planktonic foraminifers, predominantly of Late Cretaceous age, and fluidal structures marked by aligned planktonic fragments. 

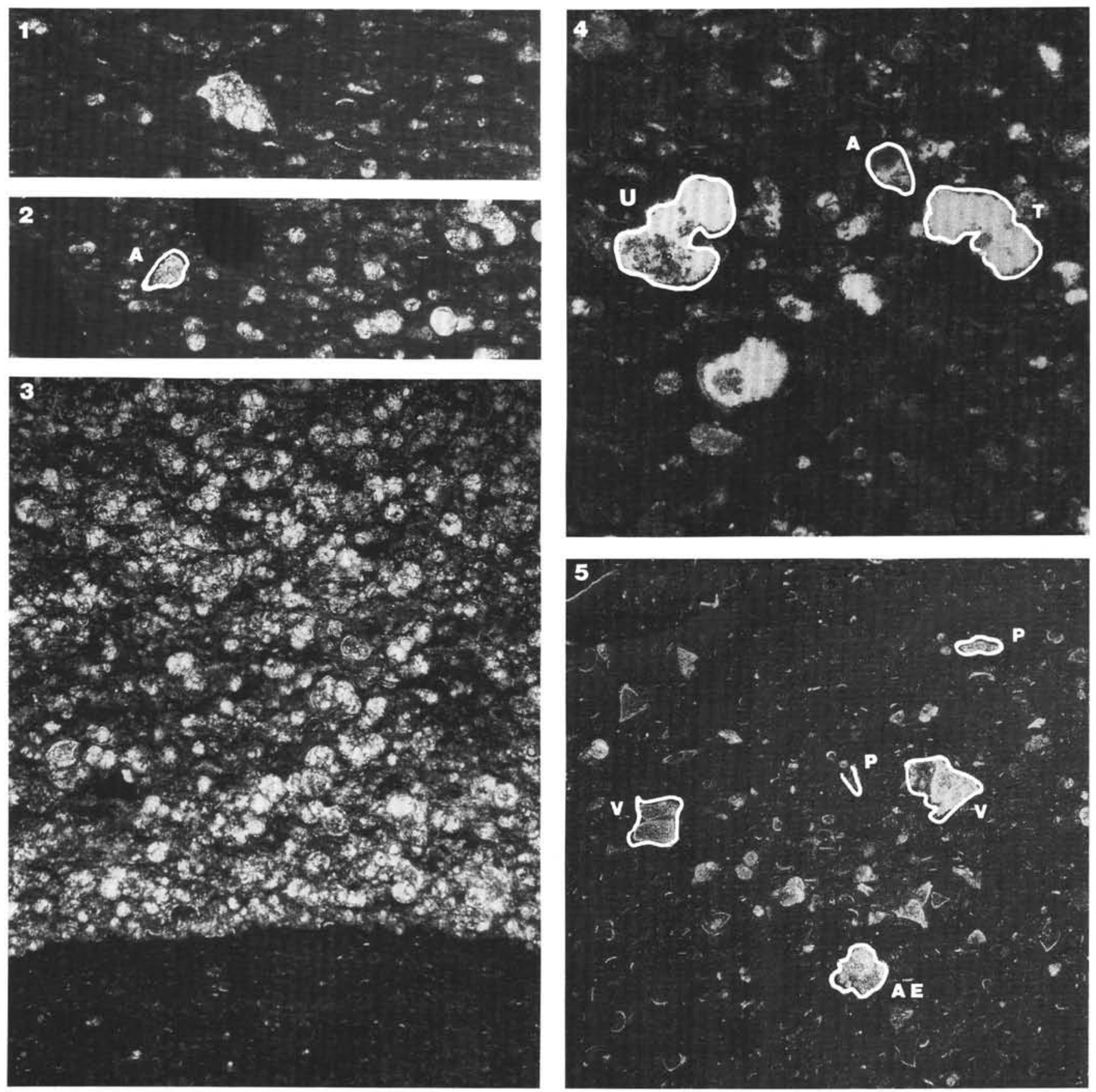

Plate 2. 1. Photomicrograph of Sample $130-807 \mathrm{C}-54 \mathrm{R}-2,46-48 \mathrm{~cm}$, showing a dissolved facies with a single specimen of Late Cretaceous Globotruncanita stuartiformis among very small, unidentifiable and fragmented, planktonic foraminifers. Subzone P1a, early Paleocene; $\times 30$ magnification. 2. Photomicrograph of Sample 130-807C-54R-1, 130-132 cm (Sliter's sample, not listed), showing common, small-sized planktonic foraminifers and a specimen of Aragonia sp. (A), a benthic form indicative of lower bathyal environment (see Sliter and Leckie, this volume). Subzone P1b, early Paleocene; $\times 30$ magnification. 3. Photomicrograph of Sample 130-807C-53R-5, 10-12 cm, cut across the base of a turbidite. Note the absence of planktonic foraminifers (lower part) below the turbiditic layer, which, on the contrary, is packed with small- to medium-sized, slightly graded planktonic specimens, mainly belonging to the Cretaceous genera Globigerinelloides and Heterohelix. Subzone P1b, early Paleocene; $\times 30$ magnification. 4. Photomicrograph of Sample 130-807C-53R-3, 120-122 cm, showing the outline of "Morozovella" trinidadensis (T), "M." uncinata (U), and $M$. angulata $(\mathrm{A})$ in a background rich in dissolved planktonic foraminifers and fragments of radiolarians. Subzone P3b, early late Paleocene; $\times 60$ magnification. 5. Photomicrograph of Sample $130-807 \mathrm{C}-52 \mathrm{R}-2,81-83 \mathrm{~cm}$, showing a fluidal layer containing only few, identifiable planktonic foraminifers (partially dissolved) associated with a large numbers of fragmented, largely dissolved specimens. Note Morozovella velascoensis $(\mathrm{V})$, possible $M$. aequa $(\mathrm{AE})$, and fragmented specimens belonging to the Planorotalites pseudomenardii gr. $(\mathrm{P})$ among others. Zone $\mathrm{P} 4$, late Paleocene; $\times 30$ magnification. 

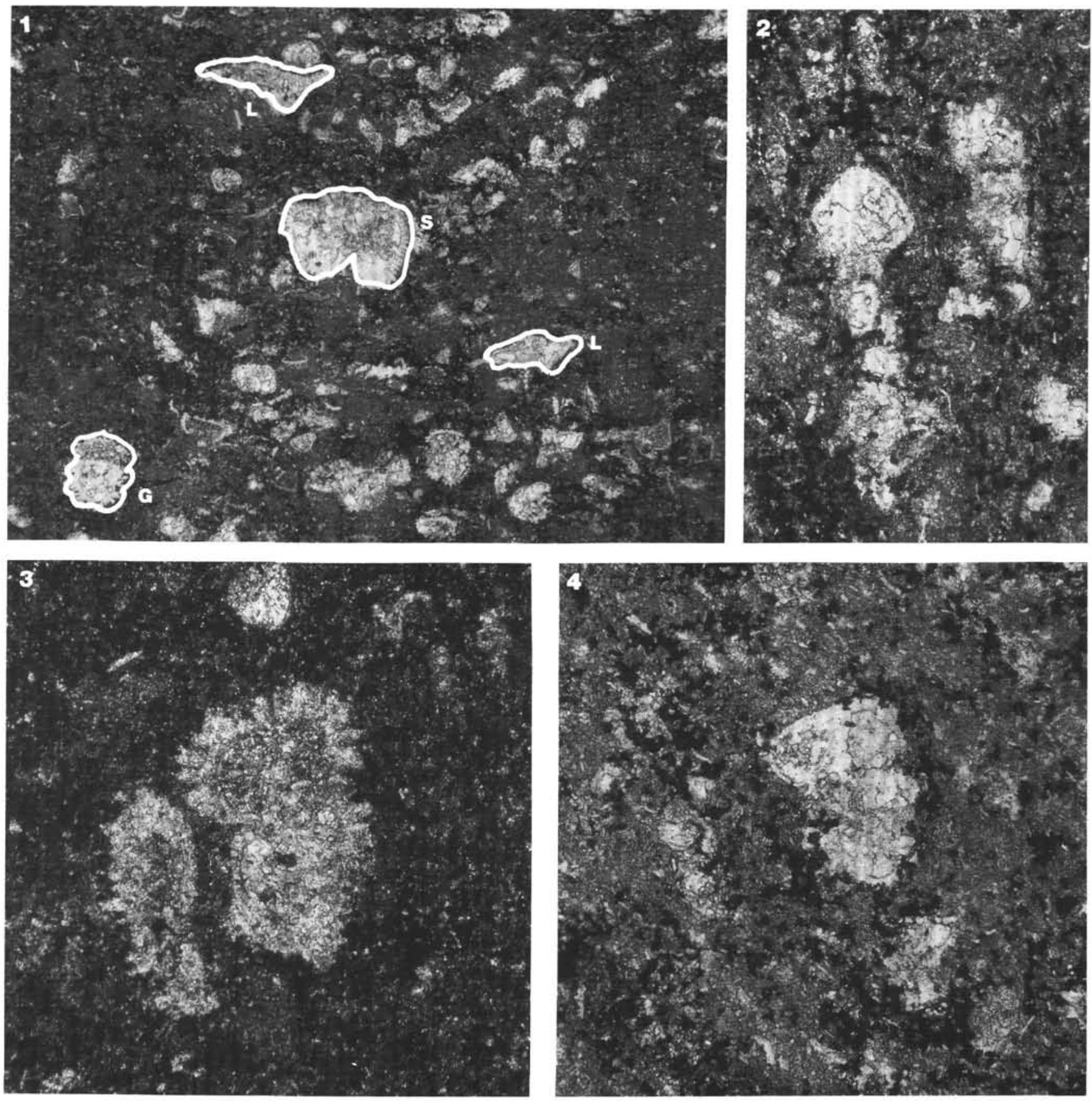

Plate 3. Photomicrographs of Sample 130-807C-51R-1, 3-5 cm. Zone P11, early middle Eocene. 1. Acarinina spinuloinflata (S), Morozovella lehneri (L), possible Globigerinatheka sp. (G). Note the numerous fragmented specimens; $\times 60$ magnification. 2. Pseudohastigerina micra/danvillensis; $\times 150$ magnification. 3. Acarinina rohri/libyaensis; $\times 150$ magnification. 4. Acarinina pseudotopilensis/topilensis; $\times 150$ magnification. 

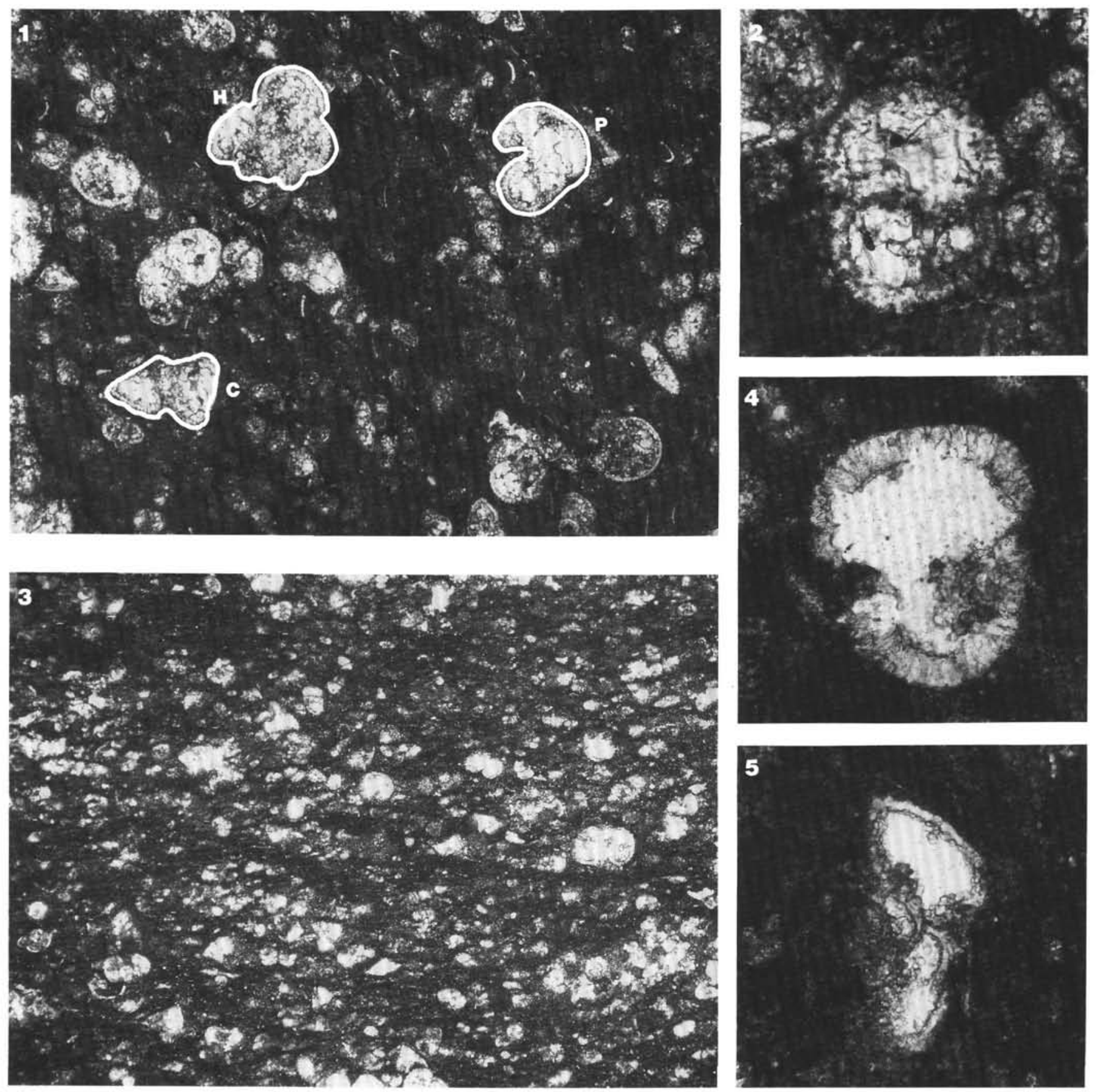

Plate 4. 1. Photomicrograph of Sample 130-807C-48R-2, 88-90 cm, showing large planktonic specimens associated with very abundant, small-sized planktonic foraminifers in a background almost devoid of micrite. Identified species include Turborotalia pomeroli (P), T. cerroazulensis form transitional to T. cocoaensis (C), and possibly "Globigerinatheka" higginsi $(\mathrm{H})$. Zones P13/P14, middle Eocene; $\times 60$ magnification. 2. Globigerinatheka sp. close to G. index. Same sample and zone as in Plate 4, Figure 1. 3. Photomicrograph of Sample 130-807C-46R-1, 30-32 cm, showing weak laminations and clear fluidal structures. Planktonic foraminifers are partially silicified and dissolved. Zones P13/P14, middle Eocene; $\times 30$ magnification. 4. Globigerinatheka index. Same sample as in Plate 4, Figure $3 ; \times 150$ magnification. 5. Turborotalia cerroazulensis cocoaensis. Same sample as in Plate 4, Figure $3 ; \times 150$ magnification. 